\title{
Sugarcane Yield Response to Furrow-Applied Organic Amendments on Sand Soils
}

\author{
J. Mabry McCray, ${ }^{1}$ Shangning Ji, ${ }^{1}$ and Leslie E. Baucum ${ }^{2}$ \\ ${ }^{1}$ Everglades Research and Education Center, University of Florida, 3200 East Palm Beach Road, Belle Glade, FL 33430, USA \\ ${ }^{2}$ Florida Cooperative Extension Service, University of Florida, 4509 George Boulevard, Sebring, FL 33875, USA
}

Correspondence should be addressed to J. Mabry McCray; jmmccray@ufl.edu

Received 7 November 2014; Revised 23 December 2014; Accepted 2 January 2015

Academic Editor: Kent Burkey

Copyright (C) 2015 J. Mabry McCray et al. This is an open access article distributed under the Creative Commons Attribution License, which permits unrestricted use, distribution, and reproduction in any medium, provided the original work is properly cited.

\begin{abstract}
Organic amendments have been shown to increase sugarcane yield on sand soils in Florida. These soils have very low water and nutrient-holding capacities because of the low content of organic matter, silt, and clay. Because of high costs associated with broadcast application, this field study was conducted to determine sugarcane yield response to furrow application of two organic amendments on sand soils. One experiment compared broadcast application $\left(226 \mathrm{~m}^{3} \mathrm{ha}^{-1}\right)$ of mill mud and yard waste compost, furrow application $\left(14,28\right.$, and $\left.56 \mathrm{~m}^{3} \mathrm{ha}^{-1}\right)$ of these materials, and no amendment. Another experiment compared furrow applications ( 28 and $56 \mathrm{~m}^{3} \mathrm{ha}^{-1}$ ) of mill mud and yard waste compost with no amendment. There were significant yield ( $\mathrm{t}$ sucrose $\mathrm{ha}^{-1}$ ) responses to broadcast and furrow-applied mill mud but responses to furrow applications were not consistent across sites. There were no significant yield responses to yard waste compost suggesting that higher rates or repeated applications of this amendment will be required to achieve results comparable to mill mud. Results also suggest that enhancing water and nutrient availability in the entire volume of the root zone with broadcast incorporation of organic amendments is the more effective approach for low organic matter sands.
\end{abstract}

\section{Introduction}

Mineral soils in sugarcane production in Florida (Entisols, Spodosols, and Alfisols) are generally very low in organic matter content and also contain very little silt or clay. These soils account for $22 \%$ of the sugarcane acreage in Florida $(36,000 \mathrm{ha})$, with sand land sugarcane area doubling in the last 25 years $[1,2]$. With all available Histosols in the Everglades Agricultural Area (EAA) already in crop production, any expansion in sugarcane acreage will be on mineral soils.

Organic amendments can be very beneficial for mineral soils with very low organic matter content by increasing cation exchange capacity and water-holding capacity in addition to supplying essential nutrients. Mill mud is a by-product of sugarcane milling and consists of a mixture of sugarcane fibers, soil, and lime added in the clarification process. Mill mud contains high concentrations of $\mathrm{N}$ and $\mathrm{P}$, but while soil $\mathrm{P}$ availability is consistently enhanced, $\mathrm{N}$ availability depends on the $\mathrm{C}: \mathrm{N}$ ratio of the mill mud and the soil type receiving the application [3]. In South Africa, Moberly and Meyer [3] determined that sugarcane yield response to mill mud was strongly related to soil $\mathrm{P}$ availability and so were able to rank soils by type and $\mathrm{P}$ availability for preference of mill mud application. In addition to nutritional benefits, soil structural improvements have been documented with mill mud application. Mill mud application improved aggregate stability in a soil in South Africa [4] and increased available soil moisture in a soil in Australia [5].

Sugarcane yield response to mill mud application has been somewhat varied depending on the specific circumstances. Samuels and Landrau [6] determined that there was no sugarcane yield response to mill mud application at rates ranging from 22 to $134 \mathrm{tha}^{-1}$ when combined with commercial fertilizer application. However, on a Florida sand soil, broadcast application of sugarcane mill mud at a rate of $224 \mathrm{tha}^{-1}$ increased 3 -year sucrose yield by $54 \%$, as compared to no organic amendment in which each treatment received standard commercial fertilizer application [7]. In 
TABLE 1: Characterization of organic amendments.

\begin{tabular}{|c|c|c|c|c|c|c|c|c|c|c|}
\hline \multirow{4}{*}{$\begin{array}{l}\text { Organic } \\
\text { material }\end{array}$} & \multirow{4}{*}{$\begin{array}{c}\text { Loss on } \\
\text { ignition } \\
\mathrm{g} \mathrm{kg}^{-1}\end{array}$} & \multirow{4}{*}{$\begin{array}{c}\text { Moisture } \\
\text { (dry basis) } \\
\\
\%\end{array}$} & \multirow{4}{*}{$\begin{array}{c}\text { Dry } \\
\text { density }^{\mathrm{a}} \\
\mathrm{g} \mathrm{L}^{-1}\end{array}$} & \multirow{2}{*}{\multicolumn{3}{|c|}{ Dry basis }} & \multicolumn{4}{|c|}{ Total applied with selected rates } \\
\hline & & & & & & & \multicolumn{2}{|c|}{$226 \mathrm{~m}^{3} \mathrm{ha}^{-1}$} & \multicolumn{2}{|c|}{$56 \mathrm{~m}^{3} \mathrm{ha}^{-1}$} \\
\hline & & & & Total N & Total P & $\begin{array}{c}\text { Water } \\
\text { soluble K }\end{array}$ & $\mathrm{N}$ & $\mathrm{P}$ & $\mathrm{N}$ & $\mathrm{P}$ \\
\hline & & & & & $\mathrm{g} \mathrm{kg}^{-1}$ & & \multicolumn{4}{|c|}{$\mathrm{kg} \mathrm{ha}^{-1}$} \\
\hline Mill Mud Site 1 & 357 & 111 & 489 & 11.3 & 21.4 & $<0.1$ & 1249 & 2365 & 309 & 586 \\
\hline Mill Mud Site 2 & 338 & 131 & 423 & 8.8 & 12.8 & $<0.1$ & $\mathrm{NA}^{\mathrm{b}}$ & NA & 208 & 303 \\
\hline Compost Site 1 & 317 & 88 & 377 & 9.9 & 3.9 & $<0.1$ & 843 & 332 & 209 & 82 \\
\hline Compost Site 2 & 412 & 86 & 476 & 7.9 & 1.6 & $<0.1$ & NA & NA & 211 & 43 \\
\hline
\end{tabular}

${ }^{\mathrm{a}}$ Dry density was determined by measuring the wet bulk density of each material as applied and also determining moisture content of each material.

${ }^{b}$ NA: not applicable. The broadcast rate of $226 \mathrm{~m}^{3} \mathrm{ha}^{-1}$ was not applied at Site 2.

South Africa, sugarcane yield responses to broadcast and furrow applications of mill mud have been documented $[4,8]$.

In addition to mill mud, other organic amendments may be viable alternatives to growers depending on location and transportation costs. Yard waste compost and other organic amendments were determined to increase soil macroporosity and water content at saturation and to decrease bulk density in the short term on loamy sand [9]. Hanlon et al. [10] suggest using compost or other organic amendments to improve sugarcane production on sands, particularly on poor producing fields or poor producing areas within fields.

If economically viable, broadcast application of organic amendments has been demonstrated to be successful in Florida [7] and this method has the advantage of amending the entire topsoil volume to the depth of incorporation. Transportation costs are a major limitation in the use of organic amendments and this is why mill mud is often applied near the sugar mill $[7,11]$. Furrow application of amendments can allow the use of relatively lower rates compared to broadcast application and so it might allow for amendment application further from a sugar mill or other sources of an amendment. Since there have been significant responses to furrow application of mill mud in some locations $[4,8]$, this could be a less expensive alternative for Florida sands with very low organic matter content. The objective of this study is to determine sugarcane yield (tonnage and sucrose) response to furrow applications of mill mud and yard waste compost on sand soils in Florida.

\section{Materials and Methods}

2.1. Experimental Design. Two field experiments were conducted on mineral soils in southern Florida, southwest (Site 1) and west (Site 2) of Lake Okeechobee. Site $1\left(26^{\circ} 45^{\prime} \mathrm{N}\right.$, $81^{\circ} 02^{\prime} \mathrm{W}$ ) was Margate sand (siliceous, hyperthermic Mollic Psammaquent) and Site $2\left(27^{\circ} 11^{\prime} \mathrm{N}, 81^{\circ} 05^{\prime} \mathrm{W}\right)$ was Basinger fine sand (siliceous, hyperthermic Spodic Psammaquent). Soil organic matter (SOM) content was determined for control plots of each site with loss on ignition. Mean SOM contents for Site 1 were $14.1(0-15 \mathrm{~cm})$ and $12.8 \mathrm{~g} \mathrm{~kg}^{-1}(15-$ $30 \mathrm{~cm})$ and for Site 2 were $13.1(0-15 \mathrm{~cm})$ and $8.8 \mathrm{~g} \mathrm{~kg}^{-1}(15-$ $30 \mathrm{~cm}$ ). These values are typical for mineral soils in southern Florida.
Experiments were randomized complete block (RCB) designs with six replications at each site. There were nine treatments at Site 1 including a control with no organic amendment, separate broadcast treatments of mill mud and yard waste compost each at a rate of $226 \mathrm{~m}^{3} \mathrm{ha}^{-1}$, and separate furrow treatments of mill mud and yard waste compost each at rates of 14, 28, and $56 \mathrm{~m}^{3} \mathrm{ha}^{-1}$. There were five treatments at Site 2 including a control with no organic amendment and separate furrow treatments of mill mud and yard waste compost each at rates of 28 and $56 \mathrm{~m}^{3} \mathrm{ha}^{-1}$. Broadcast applications at Site 1 were applied by hand to the soil surface and diskincorporated prior to opening the furrows for planting. All furrow amendment applications were applied by hand in the furrows before fertilization and planting. Characterization of mill mud and yard waste compost applied at each site is shown in Table 1. Total N, total $\mathrm{P}$, and water soluble $\mathrm{K}$ determinations of mill mud and yard waste compost were made with AOAC methods 978.02, 958.01, and 958.02, respectively. Mill mud used in each experiment was dug from storage ponds at a nearby sugar mill. Fertilization was done uniformly for all treatments in each experiment based on University of Florida soil-test recommendations [12] for soil samples taken before treatment application. Fertilizer was applied in the furrow before planting $(\mathrm{N}, \mathrm{P}, \mathrm{K}, \mathrm{Mg}, \mathrm{Mn}, \mathrm{Zn}$, $\mathrm{Cu}$, and $\mathrm{B}$ ) with later applications being made as sidedress applications on each side of the row (for plant cane and ratoon cane supplements of $\mathrm{N}$ and $\mathrm{K}$ or early ratoon application of $\mathrm{N}, \mathrm{P}$, and $\mathrm{K}$ ) or aerial applications of $\mathrm{N}$ and/or K during late spring or summer each year.

Sugarcane in each experiment was planted vegetatively by placing pairs of whole sugarcane stalks side by side in the furrows by hand and chopping them into billet lengths of approximately $60 \mathrm{~cm}$ before closing the furrows. Sugarcane cultivar CP 78-1628 was planted at Site 1 on 19 November 2005. Sugarcane cultivar CP 84-1591 was planted at Site 2 on 8 November 2007.

2.2. Soil and Leaf Sampling and Analyses. Soil samples were taken in the row to a depth of $0-15 \mathrm{~cm}$ in all plots of replications 1, 3, 4, and 6 after plant cane and first ratoon harvests at each site. Soil samples were placed in aluminum drying pans, air-dried in a forced air drying room at $31^{\circ} \mathrm{C}$, 
and sieved through a $2 \mathrm{~mm}$ screen before analysis. Soilwater $\mathrm{pH}$ was determined using a $1: 2 \mathrm{soil} /$ water ratio. Waterextractable $\mathrm{P}$ was determined with deionized water using a $4 \mathrm{~cm}^{3}$ soil $/ 50 \mathrm{~mL}$ extractant ratio. Soil samples were allowed to stand in the extractant overnight and then were shaken for 50 min before filtering for $\mathrm{P}$ analysis. Phosphorus concentrations were determined with a probe colorimeter $(880 \mathrm{~nm})$ (Brinkmann Model PC800) using the phosphomolybdate blue method [13]. Potassium, $\mathrm{Ca}, \mathrm{Mg}$, and $\mathrm{Si}$ were extracted with $0.5 \mathrm{M}$ acetic acid using a $10 \mathrm{~cm}^{3}$ soil $/ 25 \mathrm{~mL}$ extractant ratio. Soil samples were allowed to stand overnight and then were shaken for $50 \mathrm{~min}$ before filtering for analysis. Concentrations of $\mathrm{K}, \mathrm{Ca}$, and $\mathrm{Mg}$ were determined with atomic absorption spectroscopy (Agilent Model AA220FS). Silicon concentrations were determined at $670 \mathrm{~nm}$ with a probe colorimeter [14].

Leaf samples were collected in June-July each year. Twenty-four top visible dewlap (TVD) leaves were collected at random from the middle four rows of each plot. Leaf midribs were separated from leaf blades and discarded before washing the blades in deionized water and drying at $60^{\circ} \mathrm{C}$. The dried leaf material was ground to pass a $1 \mathrm{~mm}$ screen in a Wiley mill. All ground samples were dried overnight at $65^{\circ} \mathrm{C}$ before weighing for digestions. Leaf samples were digested by dry ashing at $500^{\circ} \mathrm{C}$ and dissolving in hydrochloric acid. Leaf $\mathrm{P}, \mathrm{K}, \mathrm{Mg}, \mathrm{Fe}, \mathrm{Mn}, \mathrm{Zn}$, and $\mathrm{Cu}$ concentrations were determined for each of these digests by ICP spectroscopy (Perkin Elmer Model Optima 5300DV). Leaf N concentrations were determined with Kjeldahl digestion in an aluminum digestion block and determination of $\mathrm{NH}_{4}^{+}$ concentration at $660 \mathrm{~nm}$ with a spectrophotometer (Unico Model 2100). Leaf Si digestions for all leaf samples were performed with autoclave-induced digestion [14] and leaf Si concentrations were determined at $670 \mathrm{~nm}$ with a probe colorimeter.

2.3. Yield Measurements. Stalk counts and stalk weights were used to calculate $\mathrm{t}$ cane $\mathrm{ha}^{-1}(\mathrm{TCH})$ at each site. Millable stalks were counted in two of the middle four rows of each plot in August-September each crop year. Selection of the two rows for counting was based on representative stand uniformity. A 40-stalk random sample was used to determine fresh stalk weight, and TCH was calculated as the product of stalk number and stalk weight. For the 40 -stalk sample, 20 consecutive stalks were collected in each of two of the four middle rows, taking care to sample consecutive stools from sections with representative sugarcane stand and not to take samples within $2 \mathrm{~m}$ of row ends. To determine $\mathrm{kg}$ sucrose $\mathrm{t}^{-1}$ cane (KST), a random 10-stalk sample (5 random stalks from each 20-stalk sample from an individual plot row) at harvest was milled and the crusher juice analyzed for Brix (a measure of percent soluble solids) and pol (a measure of polarization expressed as $Z^{\circ}$ ) using a NIR analyzer (Foss NIR Systems Model 5000) which has been calibrated for sucrose analysis of sugarcane in Florida. The KST was determined according to the theoretical recoverable sugar method [15]. The TSH was calculated as the product of TCH and KST (divided by 1000 to convert $\mathrm{kg}$ sucrose to metric tons).
Stalk weight measurements were performed for the plant cane and first ratoon crops at Site 1 on 4 and 6 December 2006 and 13-14 November 2007, respectively. Stalk weight measurements were performed for the plant cane, first ratoon, and second ratoon crops at Site 2 on 24-25 November 2008, 18 and 24 November 2009, and 30 November and 1 December 2010, respectively. Complete replications were sampled on each day of harvest sampling. Samples were milled for KST determination the morning after harvest samples were taken. After yield samples were taken, the remaining sugarcane was harvested commercially with combine harvesters. Site 1 plots were harvested on 3 February 2007 (plant cane) and 7 January 2008 (first ratoon). Site 2 plots were harvested on 21 January 2009 (plant cane), 5 January 2010 (first ratoon), and 20 January 2011 (second ratoon). The trial at Site 1 was not continued for the second ratoon crop because of overall poor yields in first ratoon.

2.4. Statistical Analyses. All statistical analyses were performed using SAS version 9.2 [16]. Analysis of variance was performed for TCH, TSH, and KST for Site 1 using the PROC MIXED procedure for a RCB design in a two-factor mixed effects model with crop year (plant cane or first ratoon) and treatment (nine organic amendment treatments including the control) treated as fixed effects and replication treated as a random effect. The same analysis was also performed for Site 2 but there were three crop years (plant cane, first ratoon, and second ratoon) and five organic amendment treatments. Analysis of variance was performed for harvest, soil, and leaf parameters for individual crops at Sites 1 and 2 and for total cumulative TSH for all crops at each site using the PROC MIXED procedure for a RCB design with treatment treated as a fixed effect and replication treated as a random effect. For each individual crop year data set and each cumulative TSH data set, predicted least squares means were determined for each treatment. Preplanned orthogonal contrasts were used to compare treatment means. Significance for $F$-tests and preplanned contrasts was based on a probability value of $P \leq 0.10$ rather than 0.05 because of inherent high variability encountered in the mineral soils in the study.

\section{Results}

3.1. Sugarcane Yield Response. At Site 1 there were no significant $(P \leq 0.10)$ organic amendment treatment affects across crop years for TCH, TSH, or KST (Table 2). Crop year significantly influenced each of these parameters. There was a significant interaction between crop and treatment for KST. As indicated by the overall $F$-tests, there were no significant differences in TSH for plant cane, first ratoon, or cumulative 2-year total (Table 3). However, the contrast between the broadcast mill mud treatment (T2) and the control (T1) was significant for TSH in the plant cane crop, with TSH being 19.3\% higher with broadcast mill mud compared to the control that year. Sucrose yields overall decreased substantially in the first ratoon crop and there were no significant contrasts among treatments in that crop. With cumulative TSH being $19.8 \%$ higher with broadcast 
TABle 2: For fixed effects in analyses of Sites 1 and $2, P>F$ for $t$ cane ha ${ }^{-1}(\mathrm{TCH}), \mathrm{t}$ sucrose ha ${ }^{-1}$ (TSH), and sucrose concentration $(\mathrm{KST})^{\mathrm{a}}$.

\begin{tabular}{lccc}
\hline Source & TCH & $\begin{array}{c}\text { TSH } \\
P>F\end{array}$ & KST \\
\hline Crop & & Site 1 & \\
Treatment & $<0.001$ & $<0.001$ & $<0.001$ \\
Crop $\times$ treatment & 0.106 & 0.133 & 0.167 \\
& 0.875 & 0.838 & 0.010 \\
Crop & & Site 2 & \\
Treatment & $<0.001$ & $<0.001$ & $<0.001$ \\
Crop $\times$ treatment & 0.002 & 0.027 & 0.536 \\
\hline
\end{tabular}

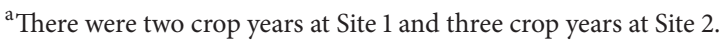

TABLE 3: Predicted least squares means and $P>F$ for t sucrose ha ${ }^{-1}$ (TSH) for individual crop years and cumulative 2-year total at Site 1. Also included are significant contrasts.

\begin{tabular}{lccc}
\hline Treatment $^{\mathrm{a}}$ & Plant cane & $\begin{array}{c}\text { 1st ratoon } \\
\text { t sucrose ha }\end{array}$ & $\begin{array}{c}\text { 2-year total } \\
(\mathrm{TSH})\end{array}$ \\
\hline (1) Control & 15.27 & 5.33 & 20.44 \\
$(2) \mathrm{MM}\left(226 \mathrm{~m}^{3} \mathrm{ha}^{-1}\right)$ & 18.22 & 6.56 & 24.49 \\
$(3) \mathrm{CP}\left(226 \mathrm{~m}^{3} \mathrm{ha}^{-1}\right)$ & 17.10 & 5.77 & 22.58 \\
$(4) \mathrm{MM}\left(14 \mathrm{~m}^{3} \mathrm{ha}^{-1}\right)$ & 15.30 & 5.02 & 20.19 \\
$(5) \mathrm{MM}\left(28 \mathrm{~m}^{3} \mathrm{ha}^{-1}\right)$ & 17.06 & 6.47 & 23.35 \\
$(6) \mathrm{MM}\left(56 \mathrm{~m}^{3} \mathrm{ha}^{-1}\right)$ & 15.31 & 5.73 & 20.94 \\
$(7) \mathrm{CP}\left(14 \mathrm{~m}^{3} \mathrm{ha}^{-1}\right)$ & 16.28 & 4.85 & 20.86 \\
$(8) \mathrm{CP}\left(28 \mathrm{~m}^{3} \mathrm{ha}^{-1}\right)$ & 17.57 & 5.97 & 23.34 \\
$(9) \mathrm{CP}\left(56 \mathrm{~m}^{3} \mathrm{ha}^{-1}\right)$ & 15.66 & 5.90 & 21.39 \\
\hline$P>F$ & 0.124 & 0.787 & 0.156 \\
Contrasts & & & $*$ \\
T1 versus T2 & $*$ & $\mathrm{NS}$ & \\
T4 versus T5 & $\mathrm{NS}$ & $\mathrm{NS}$ & $\dagger$ \\
\hline
\end{tabular}

$\overline{\dagger, *}$ Significant differences between specified treatments at $P \leq 0.10$ or 0.05 , respectively.

NS: no significant difference at $P \leq 0.10$ for the specified contrast.

${ }^{a} \mathrm{MM}$ : mill mud; CP: yard waste compost. Treatments 2 and 3 were broadcast prior to planting and treatments 4-9 were applied in the furrow prior to planting.

${ }^{\mathrm{b}}$ Other nonsignificant contrasts performed were $\mathrm{T} 1$ versus $\mathrm{T} 3$; $\mathrm{T} 1$ versus $\mathrm{T} 4$, $\mathrm{T} 5$, and $\mathrm{T} 6$; $\mathrm{T} 1$ versus $\mathrm{T} 7, \mathrm{~T} 8$, and $\mathrm{T}$; $\mathrm{T} 5$ versus $\mathrm{T} 6$; $\mathrm{T} 7$ versus $\mathrm{T} 8$; and $\mathrm{T} 8$ versus $\mathrm{T} 9$.

mill mud compared to the control, this contrast (T2 versus T1) was significant as with plant cane. Cumulative TSH with the $28 \mathrm{~m}^{3} \mathrm{ha}^{-1}$ furrow application of mill mud (T5) was significantly higher than the lower rate, but the overall contrast of furrow mill mud application across rates (T4, T5, and T6) compared to the control (T1) was not significant. Yield components of TSH (TCH, KST, stalk weight, and stalks $\mathrm{m}^{-1}$ of row) are included in Table 4 for treatments with significant treatment contrasts for TSH in Table 3 to determine which yield components were most important in differences in TSH. The increase in TSH with broadcast mill mud application can be attributed to an increase in $\mathrm{TCH}$
TABle 4: Predicted least squares means and $P>F$ for yield components including $\mathrm{t}$ cane ha $\left.\mathrm{ha}^{-1} \mathrm{TCH}\right)$ and $\mathrm{kg}$ sucrose $\mathrm{t}^{-1}$ cane (KST) for the plant cane crop at Site 1. Also included are significant contrasts.

\begin{tabular}{lcccc}
\hline Treatment $^{\mathrm{a}}$ & $\mathrm{TCH}$ & $\mathrm{KST}$ & Stalk Wt $(\mathrm{kg})$ & Stalks m$^{-1}$ \\
\hline (1) Control & 115.0 & 133.0 & 1.09 & 16.1 \\
$(2) \mathrm{MM}\left(226 \mathrm{~m}^{3} \mathrm{ha}^{-1}\right)$ & 135.7 & 134.5 & 1.38 & 15.0 \\
$(4) \mathrm{MM}\left(14 \mathrm{~m}^{3} \mathrm{ha}^{-1}\right)$ & 113.7 & 134.7 & 1.09 & 16.0 \\
$(5) \mathrm{MM}\left(28 \mathrm{~m}^{3} \mathrm{ha}^{-1}\right)$ & 125.8 & 135.6 & 1.21 & 15.9 \\
\hline$P>F$ & 0.100 & 0.046 & 0.023 & 0.211 \\
Contrasts $^{\mathrm{b}}$ & & & & \\
$\quad$ T1 versus T2 & $*$ & $\mathrm{NS}$ & $* * *$ & $*$ \\
\hline
\end{tabular}

${ }^{*, * * *}$ Significant differences between specified treatments at $P<0.05$ or 0.001 , respectively.

NS: no significant difference at $P \leq 0.10$ for the specified contrast.

${ }^{a} \mathrm{MM}$ : mill mud. Treatment 2 was broadcast prior to planting and treatments 4 and 5 were applied in the furrow prior to planting. These treatments are presented from the full ANOVA for all treatments because there were significant contrasts involving them for TSH.

${ }^{\mathrm{b}}$ The $\mathrm{T} 4$ versus $\mathrm{T} 5$ contrast was nonsignificant for yield parameters presented here.

TABle 5: Predicted least squares means and $P>F$ for $\mathrm{t}$ sucrose ha ${ }^{-1}$ (TSH) for individual crop years and cumulative 3-year total at Site 2. Also included are significant contrasts.

\begin{tabular}{lcccc}
\hline Treatment & Plant \\
cane & $\begin{array}{c}\text { 1st } \\
\text { ratoon } \\
\text { t sucrose ha }\end{array}$ & $\begin{array}{c}\text { 2nd } \\
\text { ratoon }\end{array}$ & $\begin{array}{c}\text { 3-year } \\
\text { total }\end{array}$ \\
\hline (1) Control & 15.46 & 12.50 & 14.22 & 42.18 \\
$(2) \mathrm{MM}\left(28 \mathrm{~m}^{3} \mathrm{ha}^{-1}\right)$ & 15.24 & 14.59 & 14.92 & 44.74 \\
$(3) \mathrm{MM}\left(56 \mathrm{~m}^{3} \mathrm{ha}^{-1}\right)$ & 15.36 & 14.53 & 16.18 & 46.06 \\
$(4) \mathrm{CP}\left(28 \mathrm{~m}^{3} \mathrm{ha}^{-1}\right)$ & 15.57 & 13.84 & 15.42 & 44.83 \\
$(5) \mathrm{CP}\left(56 \mathrm{~m}^{3} \mathrm{ha}^{-1}\right)$ & 15.36 & 12.24 & 14.28 & 41.87 \\
\hline$P>F$ & 0.988 & 0.010 & 0.163 & 0.052 \\
Contrasts & & & & \\
T1 versus T2 and T3 & $\mathrm{NS}$ & $* *$ & $\dagger$ & $*$ \\
T4 versus T5 & $\mathrm{NS}$ & $*$ & $\mathrm{NS}$ & $\dagger$ \\
\hline
\end{tabular}

${ }_{\dagger, *, * *}$ Significant differences between specified treatments at $P \leq 0.10,0.05$, or 0.01 , respectively.

NS: no significant difference at $P \leq 0.10$ for the specified contrast.

${ }^{a} \mathrm{MM}$ : mill mud; CP: yard waste compost. All mill mud and compost treatments were applied in the furrow prior to planting.

${ }^{\mathrm{b}}$ Other nonsignificant contrasts performed were $\mathrm{T} 2$ versus $\mathrm{T} 3$ and $\mathrm{T} 1$ versus $\mathrm{T} 4$ and $\mathrm{T} 5$.

(tonnage) and not KST (sucrose) (Table 4). This increase in $\mathrm{TCH}$ is further attributable to an increase in stalk weight with a slight decrease in stalk population with broadcast mill mud.

At Site 2, organic amendment treatments resulted in significant differences in TCH and TSH across crop years (Table 2). Crop year significantly influenced $\mathrm{TCH}, \mathrm{TSH}$, and KST. There were no significant interactions between crop and treatment for these parameters. Although these interactions were not significant, of the three crop years only the first ratoon crop resulted in a significant $F$-test for TSH (Table 5). The contrast between the control (T1) and the furrow mill mud applications (T2 and T3) was significant 
TABle 6: Predicted least squares means and $P>F$ for yield components including $\mathrm{t}$ cane ha $\mathrm{h}^{-1} \mathrm{TCH}$ ) and $\mathrm{kg}$ sucrose $\mathrm{t}^{-1}$ cane (KST) for the first ratoon crop at Site 2. Also included are significant contrasts.

\begin{tabular}{lcccc}
\hline Treatment $^{\mathrm{a}}$ & TCH & KST & Stalk Wt $(\mathrm{kg})$ & Stalks m$^{-1}$ \\
\hline (1) Control & 92.6 & 135.1 & 1.06 & 13.3 \\
$(2) \mathrm{MM}\left(28 \mathrm{~m}^{3} \mathrm{ha}^{-1}\right)$ & 108.3 & 134.9 & 1.15 & 14.5 \\
$(3) \mathrm{MM}\left(56 \mathrm{~m}^{3} \mathrm{ha}^{-1}\right)$ & 112.2 & 129.8 & 1.13 & 15.2 \\
$(4) \mathrm{CP}\left(28 \mathrm{~m}^{3} \mathrm{ha}^{-1}\right)$ & 104.5 & 132.7 & 1.12 & 14.3 \\
$(5) \mathrm{CP}\left(56 \mathrm{~m}^{3} \mathrm{ha}^{-1}\right)$ & 89.6 & 137.2 & 1.02 & 13.4 \\
\hline$P>F$ & $<0.001$ & 0.154 & $<0.001$ & 0.029 \\
Contrasts & & & & \\
T1 versus T2 and T3 & $* * *$ & $\mathrm{NS}$ & $* *$ & $* *$ \\
T2 versus T3 & $\mathrm{NS}$ & $\dagger$ & $\mathrm{NS}$ & $\mathrm{NS}$ \\
T4 versus T5 & $* *$ & $\mathrm{NS}$ & $* *$ & $\mathrm{NS}$ \\
\hline
\end{tabular}

$\overline{\dagger, * * * * * *}$ Significant differences between specified treatments at $P \leq 0.10,0.01$, or 0.001 , respectively.

NS: no significant difference at $P \leq 0.10$ for the specified contrast.

${ }^{a} \mathrm{MM}$ : mill mud; CP: yard waste compost. All mill mud and compost treatments were applied in the furrow prior to planting.

${ }^{\mathrm{b}} \mathrm{The} \mathrm{T} 1$ versus $\mathrm{T} 4$ and $\mathrm{T} 5$ contrast was nonsignificant for yield parameters presented here.

for TSH for the first and second ratoon crops and for 3-year cumulative TSH. Cumulative TSH was 6.1 and $9.2 \%$ higher with the 28 and $56 \mathrm{~m}^{3} \mathrm{ha}^{-1}$ mill mud treatments, respectively, compared to the control. The contrast between the furrow compost applications indicated significantly lower TSH with the $56 \mathrm{~m}^{3} \mathrm{ha}^{-1}$ rate (T5) compared to the $28 \mathrm{~m}^{3} \mathrm{ha}^{-1}$ rate (T6) for the first ratoon crop and 3-year cumulative TSH. None of the preplanned contrasts indicated a significant increase in TSH with furrow-applied compost compared to the control. The significant increase in TSH with furrowapplied mill mud in the first ratoon crop can be attributed to an increase in TCH, with significant increases in stalk weight and stalk population with mill mud application (Table 6). The difference in TSH between compost application rates in the first ratoon crop can be attributed to higher TCH and stalk weight with the $28 \mathrm{~m}^{3} \mathrm{ha}^{-1}$ rate.

3.2. Leaf Nutrient Concentrations. At Site $1, F$-tests indicated significant differences in leaf $\mathrm{N}, \mathrm{P}, \mathrm{K}, \mathrm{Ca}, \mathrm{Fe}$, and $\mathrm{Mn}$ concentrations among treatments in the first ratoon crop (Table 7). Broadcast mill mud application (T2) significantly increased leaf $\mathrm{N}, \mathrm{P}, \mathrm{K}, \mathrm{Fe}$, and $\mathrm{Mn}$ concentrations compared to the control (T1). Broadcast compost application (T3) significantly increased leaf $\mathrm{N}, \mathrm{K}, \mathrm{Ca}, \mathrm{Fe}$, and $\mathrm{Zn}$ concentrations compared to the control. Furrow mill mud application resulted in a significant increase in leaf $\mathrm{Fe}$ concentration across rates (T4, T5, and T6) compared to the control. There were no other significant contrasts of leaf nutrient concentrations comparing furrow-applied mill mud or compost with the control for this crop. There were significant differences in some leaf nutrient concentrations among furrow-applied mill mud or compost rates. In leaf analyses for the plant cane crop in the previous year there were generally fewer differences than with first ratoon at Site 1. In the plant cane crop, broadcast mill mud significantly increased leaf $\mathrm{N}, \mathrm{K}$, and $\mathrm{Si}$ concentrations but significantly decreased leaf $\mathrm{Ca}, \mathrm{Mg}$, and $\mathrm{Cu}$ concentrations compared to the control (data not shown). Also, in the plant cane crop, furrow-applied mill mud decreased leaf Mn concentration compared to the control, and furrow-applied compost increased leaf $\mathrm{N}$ concentration compared to the control (data not shown).

$F$-tests indicated significant treatment differences in leaf $\mathrm{P}$ and $\mathrm{Mg}$ concentrations for the first ratoon crop at Site 2 (Table 8 ). The contrast between furrow-applied mill mud (T2 and T3) and the control (T1) determined significant increases in leaf $\mathrm{N}, \mathrm{P}, \mathrm{Mg}$, and $\mathrm{Fe}$ concentrations with mill mud application. There was also a significant increase in leaf $\mathrm{N}$ concentration with furrow-applied compost (T4 and T5) compared to the control. There were significant differences between mill mud or compost rates in leaf $\mathrm{Zn}$ and $\mathrm{K}$ concentrations, respectively. In the previous year's plant cane crop the only significant contrasts of furrow-applied mill mud or compost with the control demonstrated that mill mud significantly increased leaf $\mathrm{Si}$ concentration and decreased leaf $\mathrm{Mn}$ and $\mathrm{Cu}$ concentrations compared to the control (data not shown). In the second ratoon crop, mill mud application significantly increased leaf $\mathrm{N}$ and $\mathrm{Si}$ concentrations, and compost application significantly increased leaf $\mathrm{N}$ concentration compared to the control (data not shown).

3.3. Soil-Extractable Nutrients. At Site 1, F-tests indicated significant differences in soil $\mathrm{pH}$ and extractable $\mathrm{P}, \mathrm{K}, \mathrm{Ca}$, and $\mathrm{Mg}$ among treatments after the plant cane crop (Table 9). Broadcast mill mud application (T2) significantly increased extractable P, K, and Ca compared to the control (T1). Broadcast compost application (T3) significantly increased $\mathrm{pH}$ and extractable $\mathrm{K}, \mathrm{Ca}$, and $\mathrm{Mg}$ compared to the control. Furrowapplied compost (T7, T8, and T9) significantly increased extractable $\mathrm{Ca}$ and $\mathrm{Mg}$. There were also significant differences in extractable $\mathrm{Ca}$ and $\mathrm{Si}$ between the 28 and $56 \mathrm{~m}^{3} \mathrm{ha}^{-1}$ rates of compost.

One year later, after the first ratoon crop at Site 1, broadcast mill mud application resulted in significant increases in extractable $\mathrm{P}, \mathrm{K}$, and $\mathrm{Mg}$, with significant reduction in extractable Si compared to the control (data not shown). At that time broadcast compost application resulted in significant increases in $\mathrm{pH}$ and extractable $\mathrm{Ca}$ and $\mathrm{Mg}$ (data not shown). Furrow application of mill mud resulted in significant increases in extractable $\mathrm{P}$ and $\mathrm{Mg}$, while furrow application of compost significantly increased $\mathrm{pH}$ and extractable $\mathrm{Ca}$ and $\mathrm{Mg}$ (data not shown).

At Site 2, F-tests indicated significant differences in soil $\mathrm{pH}$ and extractable $\mathrm{P}$ and $\mathrm{K}$ among treatments after the plant cane crop (Table 10). The contrast between furrowapplied mill mud treatments (T2 and T3) and the control (T1) demonstrated significant increases in extractable P and $\mathrm{Ca}$ and significant decreases in extractable $\mathrm{K}$ and $\mathrm{Si}$ with mill mud application. Furrow-applied compost (T4 and T5) significantly increased soil $\mathrm{pH}$ and extractable $\mathrm{P}$ compared to the control. After the first ratoon crop at Site 2, furrowapplied mill mud resulted in increased extractable $\mathrm{P}$ and $\mathrm{Ca}$ compared to the control (data not shown). In that sampling, 
TABLe 7: Predicted least squares means, $P>F$, and significant contrasts for leaf nutrient concentrations for the first ratoon crop at Site 1. Critical leaf nutrient concentrations [19] are included for comparison.

\begin{tabular}{|c|c|c|c|c|c|c|c|c|c|c|}
\hline \multirow{2}{*}{ Treatment $^{\mathrm{a}}$} & $\mathrm{N}$ & $\mathrm{P}$ & $\mathrm{K}$ & $\mathrm{Ca}$ & $\mathrm{Mg}$ & $\mathrm{Si}$ & $\mathrm{Fe}$ & $\mathrm{Mn}$ & $\mathrm{Zn}$ & $\mathrm{Cu}$ \\
\hline & \multicolumn{6}{|c|}{$\mathrm{g} \mathrm{kg}^{-1}$} & \multicolumn{4}{|c|}{$\mathrm{mg} \mathrm{kg}^{-1}$} \\
\hline (1) Control & 19.2 & 2.12 & 9.2 & 3.6 & 2.0 & 5.9 & 46 & 20 & 16 & 4.2 \\
\hline (2) $\mathrm{MM}\left(226 \mathrm{~m}^{3} \mathrm{ha}^{-1}\right)$ & 21.3 & 2.45 & 10.1 & 3.8 & 2.2 & 6.6 & 51 & 24 & 17 & 4.3 \\
\hline (3) $\mathrm{CP}\left(226 \mathrm{~m}^{3} \mathrm{ha}^{-1}\right)$ & 20.4 & 2.09 & 9.9 & 4.1 & 2.1 & 5.5 & 51 & 18 & 18 & 4.9 \\
\hline (4) $\mathrm{MM}\left(14 \mathrm{~m}^{3} \mathrm{ha}^{-1}\right)$ & 18.8 & 2.12 & 9.3 & 3.6 & 2.1 & 5.3 & 48 & 19 & 16 & 4.4 \\
\hline (5) $\mathrm{MM}\left(28 \mathrm{~m}^{3} \mathrm{ha}^{-1}\right)$ & 19.4 & 2.18 & 8.9 & 3.8 & 2.1 & 5.8 & 48 & 20 & 16 & 4.2 \\
\hline (6) $\mathrm{MM}\left(56 \mathrm{~m}^{3} \mathrm{ha}^{-1}\right)$ & 20.5 & 2.30 & 9.7 & 4.1 & 2.3 & 5.6 & 51 & 20 & 17 & 4.7 \\
\hline (7) $\mathrm{CP}\left(14 \mathrm{~m}^{3} \mathrm{ha}^{-1}\right)$ & 19.4 & 2.07 & 9.0 & 3.8 & 2.1 & 5.7 & 46 & 18 & 16 & 5.6 \\
\hline (8) $\mathrm{CP}\left(28 \mathrm{~m}^{3} \mathrm{ha}^{-1}\right)$ & 19.0 & 2.06 & 8.9 & 3.9 & 2.1 & 5.5 & 49 & 19 & 16 & 4.2 \\
\hline (9) $\mathrm{CP}\left(56 \mathrm{~m}^{3} \mathrm{ha}^{-1}\right)$ & 19.6 & 2.12 & 9.3 & 3.7 & 2.1 & 4.4 & 48 & 17 & 17 & 4.9 \\
\hline$P>F$ & 0.004 & $<0.001$ & 0.023 & 0.027 & 0.631 & 0.108 & 0.036 & 0.004 & 0.518 & 0.804 \\
\hline \multicolumn{11}{|l|}{ Contrasts $^{\mathrm{b}}$} \\
\hline $\mathrm{T} 1$ versus $\mathrm{T} 2$ & $* *$ & $* * *$ & * & NS & NS & NS & $* *$ & $*$ & NS & NS \\
\hline $\mathrm{T} 1$ versus $\mathrm{T} 3$ & $\dagger$ & NS & $\dagger$ & $* *$ & NS & NS & $*$ & NS & $\dagger$ & NS \\
\hline $\mathrm{T} 1$ versus $\mathrm{T} 4, \mathrm{~T} 5$, and $\mathrm{T} 6$ & NS & NS & NS & NS & NS & NS & $\dagger$ & NS & NS & NS \\
\hline T5 versus T6 & $\dagger$ & NS & NS & $\dagger$ & NS & NS & $\dagger$ & NS & NS & NS \\
\hline T7 versus T8 & NS & NS & NS & NS & NS & NS & $\dagger$ & NS & NS & NS \\
\hline $\mathrm{T} 8$ versus $\mathrm{T} 9$ & NS & NS & NS & NS & NS & $\dagger$ & NS & NS & NS & NS \\
\hline Critical leaf values & 18.0 & 1.90 & 9.0 & 2.0 & 1.3 & 5.0 & 50 & 16 & 15 & 3.0 \\
\hline
\end{tabular}

$\dagger, *, * *, * * *$ Significant differences between specified treatments at $P \leq 0.10,0.05,0.01$, or 0.001 , respectively.

NS: no significant difference at $P \leq 0.10$ for the specified contrast.

${ }^{a}$ MM: mill mud; CP: yard waste compost. Treatments 2 and 3 were broadcast prior to planting and treatments $4-9$ were applied in the furrow prior to planting.

${ }^{\mathrm{b}}$ Other contrasts tested in analysis of variance were treatments 1 versus 7,8 , and 9 and 4 versus 5 .

Only contrasts with significant differences were listed in the table.

TABLE 8: Predicted least squares means, $P>F$, and significant contrasts for leaf nutrient concentrations for the first ratoon crop at Site 2. Critical leaf nutrient concentrations [19] are included for comparison.

\begin{tabular}{|c|c|c|c|c|c|c|c|c|c|c|}
\hline \multirow{2}{*}{ Treatment $^{\mathrm{a}}$} & $\mathrm{N}$ & $\mathrm{P}$ & $\mathrm{K}$ & $\mathrm{Ca}$ & $\mathrm{Mg}$ & $\mathrm{Si}$ & $\mathrm{Fe}$ & $\mathrm{Mn}$ & $\mathrm{Zn}$ & $\mathrm{Cu}$ \\
\hline & \multicolumn{6}{|c|}{$\mathrm{g} \mathrm{kg}^{-1}$} & \multicolumn{4}{|c|}{$\mathrm{mg} \mathrm{kg}^{-1}$} \\
\hline (1) Control & 23.5 & 2.75 & 10.7 & 6.4 & 2.3 & 6.2 & 60 & 50 & 20 & 5.6 \\
\hline (2) $\mathrm{MM}\left(28 \mathrm{~m}^{3} \mathrm{ha}^{-1}\right)$ & 24.7 & 2.92 & 10.8 & 6.7 & 2.5 & 6.5 & 63 & 51 & 20 & 5.5 \\
\hline (3) $\mathrm{MM}\left(56 \mathrm{~m}^{3} \mathrm{ha}^{-1}\right)$ & 24.2 & 2.98 & 11.0 & 6.8 & 2.6 & 6.7 & 63 & 52 & 21 & 7.2 \\
\hline (4) $\mathrm{CP}\left(28 \mathrm{~m}^{3} \mathrm{ha}^{-1}\right)$ & 24.2 & 2.77 & 11.4 & 6.1 & 2.3 & 5.9 & 60 & 48 & 20 & 5.8 \\
\hline (5) $\mathrm{CP}\left(56 \mathrm{~m}^{3} \mathrm{ha}^{-1}\right)$ & 24.2 & 2.76 & 10.5 & 6.4 & 2.4 & 5.8 & 59 & 46 & 19 & 5.5 \\
\hline$P>F$ & 0.154 & 0.015 & 0.288 & 0.147 & 0.055 & 0.122 & 0.113 & 0.444 & 0.168 & 0.561 \\
\hline \multicolumn{11}{|l|}{ Contrasts } \\
\hline $\mathrm{T} 1$ versus $\mathrm{T} 2$ and $\mathrm{T} 3$ & * & $* *$ & NS & NS & * & NS & $\dagger$ & NS & NS & NS \\
\hline $\mathrm{T} 2$ versus $\mathrm{T} 3$ & NS & NS & NS & NS & NS & NS & NS & NS & $\dagger$ & NS \\
\hline $\mathrm{T} 1$ versus $\mathrm{T} 4$ and $\mathrm{T} 5$ & $\dagger$ & NS & NS & NS & NS & NS & NS & NS & NS & NS \\
\hline $\mathrm{T} 4$ versus $\mathrm{T} 5$ & NS & NS & $\dagger$ & NS & NS & NS & NS & NS & NS & NS \\
\hline Critical leaf values & 18.0 & 1.90 & 9.0 & 2.0 & 1.3 & 5.0 & 50 & 16 & 15 & 3.0 \\
\hline
\end{tabular}

${ }^{\dagger, *, * *}$ Significant differences between specified treatments at $P<0.10,0.05$, or 0.01 , respectively.

NS: no significant difference at $P \leq 0.10$ for the specified contrast.

${ }^{a} \mathrm{MM}$ : mill mud; CP: yard waste compost. All mill mud and compost treatments were applied in the furrow prior to planting.

furrow-applied compost resulted in increased $\mathrm{Ca}$ and $\mathrm{Mg}$ compared to the control (data not shown). After each of the plant cane and first ratoon crops, furrow-applied mill mud at the $56 \mathrm{~m}^{3} \mathrm{ha}^{-1}$ rate significantly increased $\mathrm{pH}$ and extractable Ca compared to the $28 \mathrm{~m}^{3} \mathrm{ha}^{-1}$ rate (Table 10 for plant cane). After the plant cane crop, extractable P was significantly higher at the $28 \mathrm{~m}^{3} \mathrm{ha}^{-1}$ rate of mill mud compared to the higher rate (Table 10), but the $56 \mathrm{~m}^{3}$ ha ${ }^{-1}$ rate had higher extractable $\mathrm{P}$ after first ratoon (data not shown).

\section{Discussion}

4.1. Sugarcane Yield Response. The largest relative yield response to organic amendments across crops in the study 
TABle 9: Predicted least squares means, $P>F$, and significant contrasts for $\mathrm{pH}$ and soil-extractable nutrients (in row, $0-15 \mathrm{~cm}$ depth) after the plant cane crop at Site 1.

\begin{tabular}{|c|c|c|c|c|c|c|}
\hline Treatment $^{\mathrm{a}}$ & $\mathrm{pH}$ & $\mathrm{P}$ & $\mathrm{K}$ & $\begin{array}{c}\mathrm{Ca} \\
\mathrm{g} \mathrm{m}^{-3}\end{array}$ & $\mathrm{Mg}$ & $\mathrm{Si}$ \\
\hline (1) Control & 7.14 & 3.9 & 47 & 731 & 112 & 80 \\
\hline $\begin{array}{l}\text { (2) MM } \\
\left(226 \mathrm{~m}^{3} \mathrm{ha}^{-1}\right)\end{array}$ & 6.89 & 12.3 & 71 & 1333 & 158 & 59 \\
\hline $\begin{array}{l}\text { (3) CP } \\
\left(226 \mathrm{~m}^{3} \mathrm{ha}^{-1}\right)\end{array}$ & 7.86 & 3.9 & 66 & 2317 & 219 & 99 \\
\hline $\begin{array}{l}\text { (4) } \mathrm{MM} \\
\left(14 \mathrm{~m}^{3} \mathrm{ha}^{-1}\right)\end{array}$ & 7.07 & 4.4 & 47 & 825 & 143 & 109 \\
\hline $\begin{array}{l}\text { (5) } \mathrm{MM} \\
\left(28 \mathrm{~m}^{3} \mathrm{ha}^{-1}\right)\end{array}$ & 7.12 & 4.8 & 46 & 991 & 134 & 92 \\
\hline $\begin{array}{l}\text { (6) } \mathrm{MM} \\
\left(56 \mathrm{~m}^{3} \mathrm{ha}^{-1}\right)\end{array}$ & 6.93 & 5.1 & 55 & 978 & 108 & 97 \\
\hline $\begin{array}{l}\text { (7) CP } \\
\left(14 \mathrm{~m}^{3} \mathrm{ha}^{-1}\right)\end{array}$ & 7.29 & 4.4 & 38 & 1227 & 159 & 81 \\
\hline $\begin{array}{l}\text { (8) CP } \\
\left(28 \mathrm{~m}^{3} \mathrm{ha}^{-1}\right)\end{array}$ & 7.36 & 3.3 & 49 & 1343 & 162 & 105 \\
\hline $\begin{array}{l}\text { (9) CP } \\
\left(56 \mathrm{~m}^{3} \mathrm{ha}^{-1}\right)\end{array}$ & 7.48 & 2.9 & 46 & 1678 & 191 & 70 \\
\hline$P>F$ & 0.002 & $<0.001$ & 0.022 & $<0.001$ & 0.020 & 0.238 \\
\hline \multicolumn{7}{|l|}{ Contrasts $^{\mathrm{b}}$} \\
\hline $\mathrm{T} 1$ versus $\mathrm{T} 2$ & NS & $* * *$ & * & $* *$ & NS & NS \\
\hline $\mathrm{T} 1$ versus T3 & $* *$ & NS & * & $* * *$ & $* * *$ & NS \\
\hline $\begin{array}{l}\mathrm{T} 1 \text { versus } \mathrm{T} 7 \\
\mathrm{~T} 8 \text {, and } \mathrm{T} 9\end{array}$ & NS & NS & NS & $* * *$ & $*$ & NS \\
\hline T8 versus $\mathrm{T} 9$ & NS & NS & NS & $\dagger$ & NS & $\dagger$ \\
\hline
\end{tabular}

$\overline{\dagger, *, * *, * * *}$ Significant differences between specified treatments at $P \leq 0.10$, $0.05,0.01$, or 0.001 , respectively.

NS: no significant difference at $P \leq 0.10$ for the specified contrast.

${ }^{a}$ MM: mill mud; CP: yard waste compost. Treatments 2 and 3 were broadcast prior to planting and treatments 4-9 were applied in the furrow prior to planting.

${ }^{\mathrm{b}}$ Other contrasts tested in analysis of variance were treatments 1 versus 4,5 , and $6 ; 4$ versus $5 ; 5$ versus 6 ; and 7 versus 8 . Only contrasts with significant differences were listed in the table.

was the $19.8 \%$ increase in cumulative TSH with broadcast mill mud application $\left(226 \mathrm{~m}^{3} \mathrm{ha}^{-1}\right)$ at Site 1 . Since there were no differences among treatments at either site in KST (sucrose concentration), all differences in TSH could be attributed to differences in TCH. Although there was a trend of increased TSH with broadcast compost, differences were not significant where this broadcast application was made. Higher rates or repeated applications of compost would likely be required to achieve similar yield responses to those with mill mud. At Site 2 cumulative TSH was increased by 6.1 and $9.2 \%$ with mill mud application at 28 and $56 \mathrm{~m}^{3} \mathrm{ha}^{-1}$ rates, respectively. These yield responses to furrow applications of mill mud were relatively small compared to the percentage response to broadcast mill mud application at Site 1 and the response obtained to broadcast mill mud application determined by Gilbert et al. [7] who obtained a 54\% cumulative 3-year TSH increase with a broadcast mill mud application of $224 \mathrm{tha}^{-1}$ with each treatment receiving commercial fertilizer rates.
TABle 10: Predicted least squares means, $P>F$, and significant contrasts for $\mathrm{pH}$ and soil-extractable nutrients (in row, $0-15 \mathrm{~cm}$ depth) after the plant cane crop at Site 2.

\begin{tabular}{lcccccc}
\hline Treatment & $\mathrm{pH}$ & $\mathrm{P}$ & $\mathrm{K}$ & $\begin{array}{c}\mathrm{Ca} \\
\mathrm{g} \mathrm{m}^{-3}\end{array}$ & $\mathrm{Mg}$ & $\mathrm{Si}$ \\
\hline$(1)$ Control & 6.70 & 3.3 & 42 & 801 & 79 & 61 \\
$(2) \mathrm{MM}\left(28 \mathrm{~m}^{3} \mathrm{ha}^{-1}\right)$ & 6.50 & 10.9 & 29 & 1403 & 119 & 44 \\
$(3) \mathrm{MM}\left(56 \mathrm{~m}^{3} \mathrm{ha}^{-1}\right)$ & 6.65 & 7.4 & 28 & 1132 & 97 & 42 \\
$(4) \mathrm{CP}\left(28 \mathrm{~m}^{3} \mathrm{ha}^{-1}\right)$ & 6.95 & 6.8 & 35 & 930 & 90 & 49 \\
$(5) \mathrm{CP}\left(56 \mathrm{~m}^{3} \mathrm{ha}^{-1}\right)$ & 7.24 & 5.3 & 41 & 1499 & 120 & 48 \\
\hline$P>F$ & 0.004 & 0.003 & 0.004 & 0.157 & 0.520 & 0.504 \\
Contrasts & & & & & & \\
T1 versus T2 and T3 & $\mathrm{NS}$ & $* * *$ & $* * *$ & $\dagger$ & $\mathrm{NS}$ & $\dagger$ \\
T2 versus T3 & $\mathrm{NS}$ & $*$ & $\mathrm{NS}$ & $\mathrm{NS}$ & $\mathrm{NS}$ & $\mathrm{NS}$ \\
$\mathrm{T} 1$ versus T4 and T5 & $*$ & $*$ & $\mathrm{NS}$ & $\mathrm{NS}$ & $\mathrm{NS}$ & $\mathrm{NS}$ \\
$\mathrm{T} 4$ versus T5 & $\dagger$ & $\mathrm{NS}$ & $\mathrm{NS}$ & $\dagger$ & $\mathrm{NS}$ & $\mathrm{NS}$ \\
\hline
\end{tabular}

${ }^{\dagger}, *, * * *$ Significant differences between specified treatments at $P \leq 0.10,0.05$, or 0.001 , respectively.

NS: no significant difference at $P \leq 0.10$ for the specified contrast.

${ }^{a} \mathrm{MM}$ : mill mud; CP: yard waste compost. All mill mud and compost treatments were applied in the furrow prior to planting.

Yield response to furrow-applied mill mud was also inconsistent since there was not a significant yield response to this application at Site 1 . The differences in responses between sites to furrow mill mud applications may be partially attributed to the lower SOM content in the $15-30 \mathrm{~cm}$ depth at Site $2\left(8.8 \mathrm{~g} \mathrm{~kg}^{-1}\right)$ compared to Site $1\left(12.8 \mathrm{~g} \mathrm{~kg}^{-1}\right)$. Moberly and Meyer [3] obtained yield responses to furrow-applied mill mud in some locations in South Africa with the largest responses being attributed to application to soils of low $\mathrm{P}$ status and high $\mathrm{P}$ sorption properties. South Florida sands are often relatively low in available $\mathrm{P}$ but do not have high capacity for sorption of $\mathrm{P}$ since organic matter content is low and there is very little clay in the rooting zone. With south Florida sands being very low in organic matter and clay contents, a large benefit of broadcasting an organic amendment is likely in improved water retention for the crop $[5,7]$ and this would be much more limited when the amendment is banded in a small volume of soil in the furrow.

There were no significant yield responses to furrow applications of compost at either location. Lower cumulative TSH with the $56 \mathrm{~m}^{3} \mathrm{ha}^{-1}$ rate of compost compared to $28 \mathrm{~m}^{3} \mathrm{ha}^{-1}$ at Site 2 suggested that there could be problems associated with applying a high rate of this material in the furrow. Observations at application indicated that the compost included a substantial portion of woody material which could be slow to decompose and also could immobilize $\mathrm{N}$ during this process. Broadcasting compost either at higher rates or in repeated applications as suggested by Hanlon et al. [10] appears to be the better approach.

4.2. Soil and Leaf Nutrients. Broadcast mill mud application increased leaf $\mathrm{N}, \mathrm{P}$, and $\mathrm{K}$ concentrations at Site 1, but furrow mill mud applications only increased leaf $\mathrm{N}$ and $\mathrm{P}$ concentrations for ratoon crops at Site 2 with no increases 
in these leaf nutrient concentrations at Site 1 . Total $\mathrm{N}$ and $\mathrm{P}$ contents of applied mill mud were substantial $\left(11.3 \mathrm{~g} \mathrm{~N} \mathrm{~kg}^{-1}\right.$ and $21.4 \mathrm{~g} \mathrm{P} \mathrm{kg}^{-1}$ at Site 1 ) and so these nutrients were supplied by the application. However, soluble $\mathrm{K}$ content in the mill mud was low so the increase in leaf $\mathrm{K}$ with broadcast mill mud application may be partially attributed to improved nutrient retention with this application. Also, Gilbert et al. [7] determined that $328 \mathrm{~kg} \mathrm{~K} \mathrm{ha}^{-1}$ was applied in a $224 \mathrm{tha}^{-1}$ application of mill mud as estimated with a Mehlich 3 extract of the material, so mill mud can contain some Kalthough this is variable and depends on the source [8].

Total $\mathrm{P}$ also varied substantially for mill mud from Site 1 to Site 2 even though the mill mud for each location came from the same mill, though applications were two years apart. Although total P content in mill mud applied at Site 1 was higher than that applied at Site 2, furrow-applied mill mud only increased soil-extractable $\mathrm{P}$ in one of two years that soil samples were collected at Site 1 . Broadcast mill mud applications increased water-extractable $\mathrm{P}$ in the plow layer more than 3 times compared to the control at Site 1. Morris et al. [17] determined that a $224 \mathrm{tha}^{-1}$ broadcast application of mill mud to a Florida sand increased Mehlich 1-extractable $\mathrm{P}$ in the $0-15 \mathrm{~cm}$ depth by a factor of 8.4 , but that $\mathrm{P}$ was not readily leached into the subsoil. The lack of a consistent increase in nutrient availability with furrow-applied mill mud may have been an important factor in the inconsistent yield response to these applications. While some regions have effectively used mill mud as primarily nutrient source that could potentially be used at relatively low rates in furrow applications $[3,6]$, our results were mixed in terms of yield and nutrient responses to furrow applications.

Increases in leaf nutrient concentrations with compost application were generally fewer and less pronounced than with mill mud application. There were some specific increases in leaf $\mathrm{N}$ concentration with broadcast and furrow applications of compost but there were no increases in leaf $\mathrm{P}$ with compost application. This is not unexpected given the low P content of the compost materials (Table 1). Leaf samples were taken in June-July each year so if there were problems with immobilization of $\mathrm{N}$ early in the first year after compost application this may not have been evident by the time samples were taken in the summer. Also, since full commercial fertilizer rates including split $\mathrm{N}$ applications were included with all treatments in each experiment, periods of $\mathrm{N}$ insufficiency with immobilization would have been minimized.

Soil $\mathrm{pH}$ was increased by broadcast compost application. There was also a $\mathrm{pH}$ increase in the row with furrowapplied compost but this effect was not significant at all samplings. Mill mud did not have a significant influence on $\mathrm{pH}$ with broadcast or furrow applications. Compost application generally increased extractable soil Ca but these were most consistent with broadcast application. There were also increases in extractable $\mathrm{Ca}$ with mill mud application although at Site 1 soil Ca was increased more with compost application than with mill mud application. Although $\mathrm{pH}$ in control plots was near neutral (Tables 9 and 10), there was no indication that increase in $\mathrm{pH}$ or $\mathrm{Ca}$ with amendment applications was detrimental to micronutrient availability (Tables 7 and 8). There were actually some increases in leaf micronutrient concentrations with mill mud and compost applications but these tended to be minor and inconsistent. Increases in available soil $\mathrm{Ca}$ with mill mud or compost application would be beneficial in these sands which often have low Ca availability [18].

\section{Conclusions}

Although there were significant sugarcane yield (TSH) responses to furrow-applied mill mud $\left(28\right.$ and $\left.56 \mathrm{~m}^{3} \mathrm{ha}^{-1}\right)$ at one of two locations, these responses were relatively small $(<10 \%$ yield increase) and were inconsistent. Broadcast application of mill mud $\left(226 \mathrm{~m}^{3} \mathrm{ha}^{-1}\right)$ significantly increased cumulative TSH by $19.8 \%$ compared to the control where broadcast applications were included. While there were trends of increased TSH with some applications of yard waste compost, yield responses to these applications were not significant, suggesting that higher broadcast rates or repeated application of compost would be required to achieve results comparable to mill mud application. There were specific nutrient concentration increases in soil and leaves with mill mud and yard waste compost application but furrow applications of each generally resulted in less consistent increases as compared to broadcast applications. Results suggest that enhancing water and nutrient availability in the entire volume of the root zone with broadcast amendments is important in yield responses in Florida sands. With evidence of limited yield response to furrow applications, broadcast applications of organic amendments are recommended as the more effective approach for these soils.

\section{Conflict of Interests}

The authors declare that there is no conflict of interests regarding the publication of this paper.

\section{Acknowledgments}

The authors would like to thank the following growers for their participation and support of the study: Hilliard Brothers of Florida, Lykes Brothers, Inc., and United States Sugar Corporation. The study was supported by donations from the Florida Sugar Cane League, Inc., Sugarcane Industry Research Committee.

\section{References}

[1] F. J. Coale and B. Glaz, "Florida’s 1988 sugarcane variety census," Sugar y Azucar, vol. 83, no. 12, pp. 27, 30-31, 34, 1988.

[2] R. W. Rice, L. Baucum, and W. Davidson, "Sugarcane variety census: Florida 2013," Sugar Journal, vol. 77, no. 2, pp. 10-19, 2014.

[3] P. K. Moberly and J. H. Meyer, "Filter cake. A field and glasshouse evaluation," in Proceedings of the South African Sugar Technologists' Association, vol. 52, pp. 131-136, 1978. 
[4] G. Roth, "The effects of filter cake on soil fertility and yield of sugarcane," in Proceedings of the South African Sugar Technologists' Association, vol. 45, pp. 142-148, 1971.

[5] S. Kumar, R. S. Malik, and I. S. Dahiya, "Influence of different organic wastes upon water retention, transmission and contact characteristics of a sandy soil," Australian Journal of Soil Research, vol. 23, no. 2, pp. 131-136, 1985.

[6] G. Samuels and P. Landrau, "Filter-press cake as a fertilizer," in Proceedings of the International Society of Sugar Cane Technologists, vol. 9, pp. 119-131, 1956.

[7] R. A. Gilbert, D. R. Morris, C. R. Rainbolt et al., "Sugarcane response to mill mud, fertilizer, and soybean nutrient sources on a sandy soil," Agronomy Journal, vol. 100, no. 3, pp. 845-854, 2008.

[8] K. E. F. Alexander, "Filter cake," South African Sugar Journal, vol. 56, pp. 71-77, 1972.

[9] E. Arthur, W. M. Cornelis, J. Vermang, and E. de Rocker, "Amending a loamy sand with three compost types: impact on soil quality," Soil Use and Management, vol. 27, no. 1, pp. 116-123, 2011.

[10] E. A. Hanlon, R. M. Muchovej, M. Ozores-Hampton, S. Shukla, F. M. Roka, and H. Yamataki, "Sugarcane production in southwest Florida: mineral soils and amendment," Florida Cooperative Extension Service Fact Sheet SL 230, UF/IFAS Electronic Data Information Source (EDIS) Database, University of Florida, Gainesville, Fla, USA, 2011, http://edis.ifas.ufl.edu/ sc073.

[11] M. E. Qureshi, M. K. Wegener, and F. M. Mason, Mill Mud Case Study in Mackay: An Economic Study on Recycling Sugar By-Products for the Mackay Region, CRC Sugar Occasional Publication, Cooperative Research Centre for Sustainable Sugar Production, Townsville, Australia, 2000.

[12] R. W. Rice, R. A. Gilbert, and J. M. McCray, "Nutritional requirements for Florida sugarcane," Florida Cooperative Extension Service Fact Sheet SS-AGR-228, UF/IFAS Electronic Data Information Source (EDIS) Database, University of Florida, Gainesville, Fla, USA, 2010, http://edis.ifas.ufl.edu/ sc028.

[13] J. Murphy and J. P. Riley, "A modified single solution method for the determination of phosphate in natural waters," Analytica Chimica Acta, vol. 27, pp. 31-36, 1962.

[14] C. L. Elliott and G. H. Snyder, "Autoclave-induced digestion for the colorimetric determination of silicon in rice straw," Journal of Agricultural and Food Chemistry, vol. 39, no. 6, pp. 1118-1119, 1991.

[15] B. L. Legendre, "The core/press method for predicting the sugar yield from cane for use in cane payment," Sugar Journal, vol. 54, no. 9, pp. 2-7, 1992.

[16] SAS Institute, The SAS System for Windows, Version 9.2, SAS Institute, Cary, NC, USA, 2008.

[17] D. R. Morris, R. A. Gilbert, C. R. Rainbolt et al., "Sugarcane yields and soil chemical properties due to mill mud application to a sandy soil," in Proceedings of the International Society of Sugar Cane Technologists Congress (ICC '07), vol. 26, pp. 444448, Durban, South Africa, July-August 2007.

[18] R. M. C. Muchovej, Y. Luo, J. M. Shine Jr., and J. C. Jones, "Nutritional problems associated with low yield of sugarcane on mineral soils," in Proceedings of the Soil and Crop Science Society of Florida, vol. 59, pp. 146-150, 2000.

[19] J. M. McCray and R. Mylavarapu, "Sugarcane nutrient management using leaf analysis," Florida Cooperative Extension
Service Fact Sheet SS-AGR-335, UF/IFAS Electronic Data Information Source (EDIS) Database, University of Florida, Gainesville, Fla, USA, 2010, http://edis.ifas.ufl.edu/ag345. 


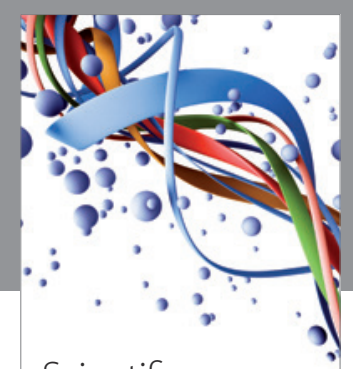

Scientifica
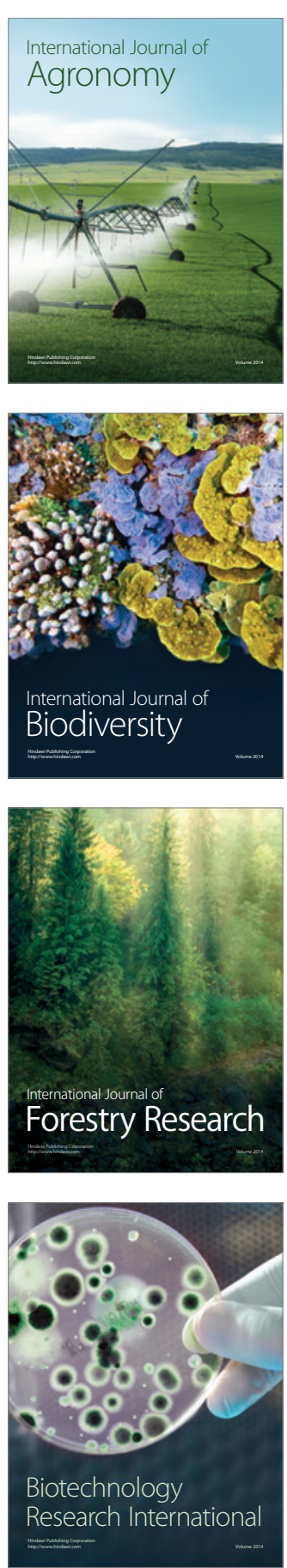
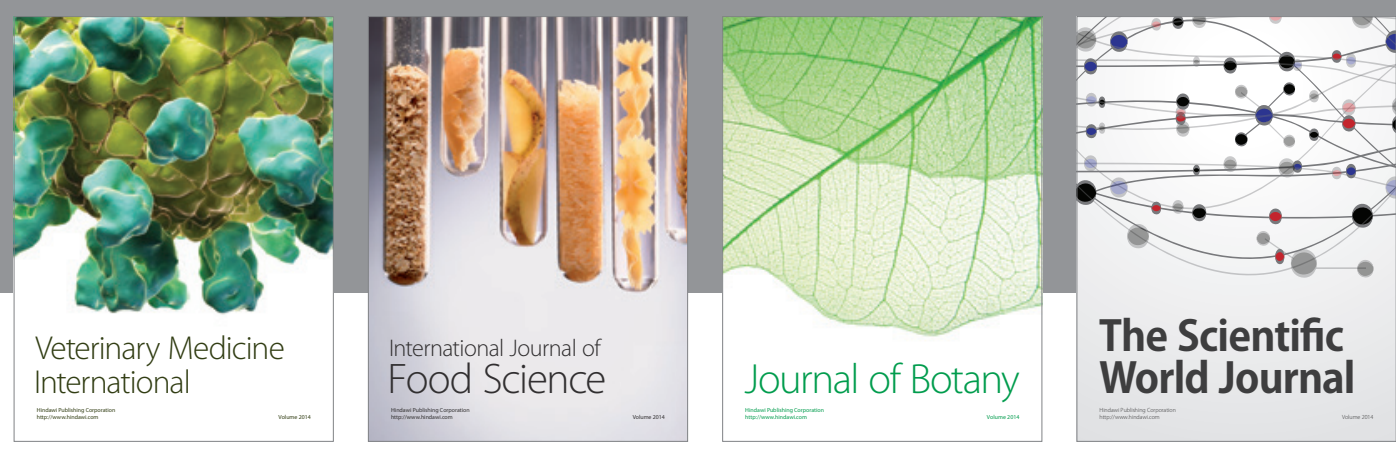

The Scientific World Journal
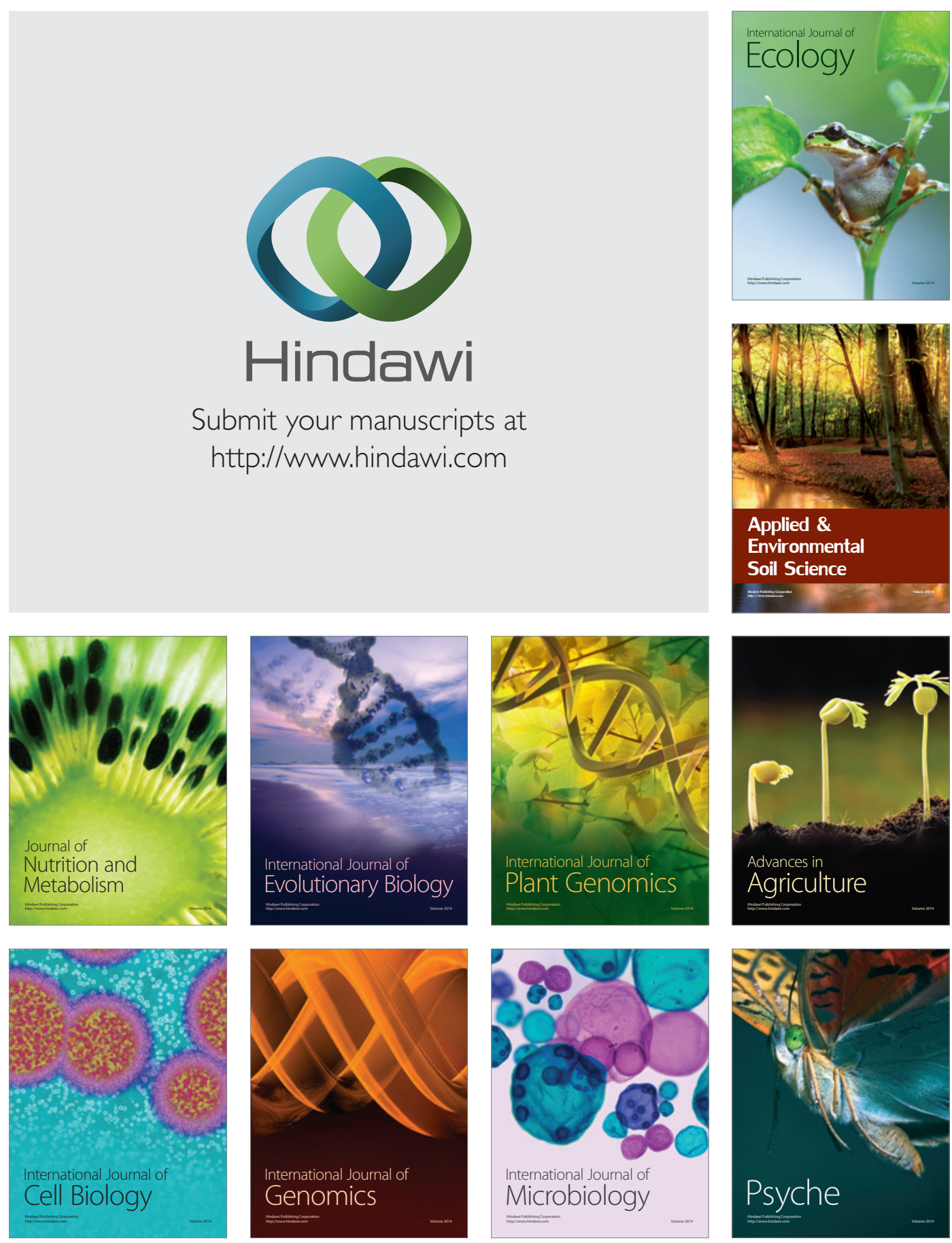